\title{
FARMER PARTICIPATION IN PARTICIPATORY IRRIGATION MANAGEMENT IN MENA KIRI, TIMOR TENGAH UTARA, INDONESIA
}

\author{
Naben P.A. ${ }^{*}$, Neolaka M.N.B.C., Gana F. \\ Master's Program in Administrative Science, Post Graduate Program, \\ Nusa Cendana University, Kupang, East Nusa Tenggara, Indonesia \\ *E-mail: musnaben69@gmail.com
}

\begin{abstract}
The objectives of the study were to describe farmer participation in participatory irrigation management, and describe and analyze supporting and inhibiting factors in participatory irrigation management. The focuses of the study were farmer or farmer's group participation in participatory irrigation management in Mena Kiri, and supporting and inhibiting factors in participatory irrigation management in Mena Kiri. The study was a qualitative study using case study. The setting of the study was Mena Kiri irrigation site located in Insana Wini, Timor Tengah Utara, Indonesia. The finding revealed that farmer's group administration did not work effectively. As the consequence, the farmer's group was unable to improve farmer's welfare. As an institution, Tai Molo farmer's group should run independently with the help of both farmers and the society.
\end{abstract}

\section{KEY WORDS}

Participation, farmer's group, irrigation, production.

Indonesia is well-known as agrarian country because most Indonesians work as farmers. Agriculture plays pivotal role in development of a country because it is closely related to food security. Agriculture involves water or irrigation system. Irrigation is one of the keys in successful harvest and government policy to maintain rice self-sufficiency (Supadi, 2009). Irrigation makes sure there is enough water although source of water is quite far (Suroso, PS. Nugroho, Pamuji, 2007). Discussing about infrastructure for irrigation, not only do we discuss about developing the infrastructure, but we also discuss about maintenance or management system. Inadequate management may result in poor maintenance of the infrastructure.

Majuar (2013) explains that general issues in irrigation system management are lacking supply of water and por maintenance. These affect irrigation system. To prevent these issues, effective irrigation management system is of necessity. In their article, Widiyanto and Krisbandono (2013) also showed that active participation of farmer's organization is a variable that influences irrigation infrastructure.

P3A is an institution established based on the concept of decentralization that is to assign tertiary irrigation system management to farmers. It indicates that the focus of national development is not government-centered any longer; instead, it has been shifted into community-centered development system. However, level of farmer's participation in the tertiary irrigation system management is still lacking. Besides that, P3A as organization is not running effectively. Ineffective P3A administration influences lacking participation of farmers in the management. For 5 years, quality of the irrigation system has not changed from tertiary into a permanent one indicating unsuccessful effort of P3A to invite farmer's participation to improve quality of the tertiary irrigation system. P3A is responsible for tertiary irrigation management and distributing water into rice fields. Improving quality of irrigation system from tertiary to permanent will solve some issues P3A frequently encounter, for example leakage or unauthorized use of water from irrigation system (water theft). Minimizing those issues will enhance quality of water and eventually rice production.

\section{LITERATURE REVIEW}

Participation. Participation is important component in developing independence and empowerment (Craig and May, 1995 as cited in Hikmat, 2004). Furthermore, Hikmat (2004) 
explains that empowerment and participation are potential strategies in improving economic, social and cultural transformation. This process, eventually, will create society-centered development. Participation, according to Hoofsteede (1971) as cited in Khairuddin (2000), means "the taking part in one or more phases of the process (of development)".

On the other hand, Fithriadi, et.al (1997) define participation as the main component in developing society-centered and sustainable development as well as continuous interactive process. Principle in participation is involving or immediate participation of the society and can only be achieved if the society takes part since the beginning of the process until the end (results). Public participation will guarantee if a process runs effectively and accurately. Therefore, Abe (2005) assumed that this causes well-trained society. Wthout pre-condition, in developing political education, direct participation from society will not be as meaningful.

Irrigation Operation and Maintenance. Ministry of Public Works Regulation number: 32/PRT/M/2007 about irrigation and irrigation system management emphasizes that irrigation system management refers to operation, maintenance and rehabilitation of irrigation system in irrigation sites. Irrigation system operation is effort to regulate water and drainage system which include water control and irrigation gates, designing water distribution plan, conducting irrigation infrastructure and water gate calibration, collecting data, supervising and evaluation. Irrigation system maintenance is effort to maintain irrigation system is working properly in order that it runs well and is sustainable.

P3A. Based on the Ministry of Public Works Regulation number 33/ PRT/ M/ 2007 P3A refers to farmer's organization responsible for irrigation management in certain tertiary irrigation site or area which is established based on democratic system including farmers and local organization responsible for irrigation management.

P3A independence is a parameter showing that organization is able to fulfill its need. Independent organization should meet the following indicators, namely: knowledge, capacity, trust, participation (Pratiwi, et.al, 2012). Public organization independence is a medium for grass-root institution to voice aspiration and affect decision-making related to local-scale public policy focusing on lower economic society pro poor (Sopandi, 2009). In order to become an independent organization, P3A should improve their management system.

\section{METHODS OF RESEARCH}

The study was a qualitative study and the type of the study was case-study. The focuses of the study were farmer or farmer's group participation in participatory irrigation management in Mena Kiri, and supporting and inhibiting factors in participatory irrigation management in Mena Kiri. The setting of the study was Mena Kiri irrigation site located in Insana Wini, Timor Tengah Utara. The informants were selected based on certain criteria (purposive). The data collection methods were interview, documentation and observation. The data analysis technique was descriptive analysis.

\section{RESULTS AND DISCUSSION}

The public (natives), the local government and the P3A administrators admitted there were several obstacles they encountered to run effective P3A. Besides lacking participation from the members and the society, the Head of of village, Humusu Oekolo and the head of Tai Molo P3A Tai Molo mentioned that certain regulations on establishment of P3A are one of the inhibiting factors for running the P3A effectively. Based on their explanations, none of the administrators had initiative to establish and issue P3A-related regulations. Some administrators argued that the local government should be the one responsible for the P3A in terms that they had authority to establish and issue regulations related to P3A as well as were responsible for membership fee, income and activities the P3A conducted. At the same time, the local government was waiting for the P3A administrators to establish and issue their own regulations. The local government would issue additional regulations once the administrators had issued their own regulations. 
Another issue was that the P3A supervised two villages and its members are natives from these two different villages. As the consequence, regulations related to the P3A may not be issued by one of the villages. Both heads of these villages should come to consensus before issuing regulations related to the P3A. It caused longer time for issuing a regulation. Worse, there is a lacking coordination between the members from the two villages.

In addition, some of the P3A members were not natives to Oekolo and Oesoko villages. The native members felt the non-natives ones had never participated or contributed in activities to improve agricultural sector in the area although they owned rice fields in these villages. The former group expected that all members had the same rights and responsibility despite which villages they were from. The P3A dependence towards the local government is alos derived from lacking human resources. The P3A administrators were not aware of either the functions of P3A in general or tasks and functions of every administrator of the P3A.

Despite of those P3A-related issues above, level and quality of participation of P3A members more particularly those who are natives of Oekolo and Oesoko villages are quite high. These members participate actively and voluntarily in every activity the P3A conducted. They attend these activities based on their own initiatives. There is some supporting and inhibiting factors in regards to low public participation in Tai Molo P3A. The inhibiting factors are (1) human resources, (2) lack of trust between the members of P3A, (3) non-natives own some parts of the land in the area, (4) poor P3A management, (5) no policy related to tasks, functions and responsibility of P3A, (6) lacking coordination between the P3A administrators. On the other hand, the supporting factors are (1) high participation of some of the P3A members, and (2) high participation quality from the active members.

\section{CONCLUSION}

P3A members' participation in participatory irrigation management in Mena Kiri is low. P3A Tai Molo administration is not working effectively. The administration is not able to carry out their tasks and functions as they should and therefore, farmers' standard of living remains low. P3A is an institution that is supposedly run by the society. The administrators are supposed to invite public participation to run the institution. Unfortunately, these are not the cases in Tai Molo P3A. Then authors suggest: P3A administrators should improve their human resource as it is the underlying reason for ineffective Tai Molo P3A. Government should contribute through workshop and training of which purpose is to improve quality of human resources in the area. P3A, regional government and related public institutions should involve P3A members who own piece of land outside Oekolo and Oesoko villages. Planning, implementation, supervision and evaluation should become focuses of human resource development program in the area. Finally, government should issue regulations on functions, tasks and responsibilities of Tai Molo P3A.

\section{REFERENCES}

1. Supadi. (2009). Dampak Impor Berkelanjutan Terhadap Ketahanan Pangan. Jurnal Analisis Kebijakan Pertanian, 7(1), 87-102.

2. Suroso, P.S. et al (2007). Evaluasi Kinerja Jaringan Irigasi Banjaran Untuk Meningkatkan Efektivitas Dan Efisiensi Pengelolaan Air Irigasi. Dinamika Teknik Sipil, 7(1), 55 - 62.

3. Widyanto, W., \& Krisbandono, A. (2013). Penentuan Variabel dan Indikator Outcome Jaringan Irigasi di Daerah Irigasi Batang Anai Sumatera Barat dengan Teknik Delphi. Jurnal Sosial Ekonomi Pekerjaan Umum, 5(3), 167-174.

4. Khairudin, S. S. (2000). Pembangunan Masyarakat Tinjauan Aspek: Sosiologi, Ekonomi dan Perencanaan. Yogyakarta: Liberti Yogyakarta.

5. Hikmat, H. (2004). Strategi Pemberdayaan Masyarakat. Bandung: Humoniora.

6. Peraturan Menteri Pekerjaan Umum Nomor 30/PRT/M/2007 tentang Pedoman Pengembangan dan Pengelolaan Sistem Irigasi Partisipatif. (2007). Pemerintah Republik Indonesia. Jakarta. 